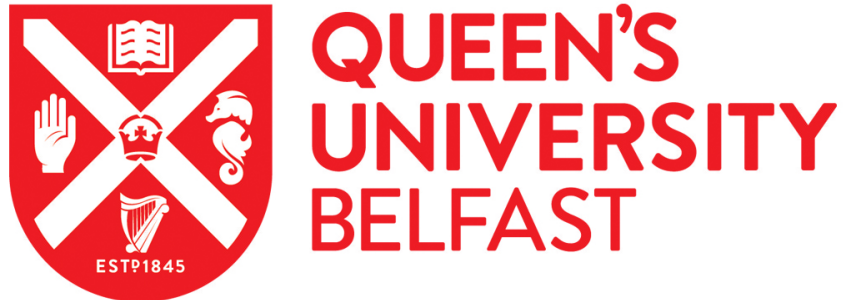

\section{Attaining Theoretical Coherence within Relationship-Based Practice in Child and Family Social Work: The Systemic Perspective}

Coulter, S., Houston, S., Mooney, S., Devaney, J., \& Davidson, G. (2019). Attaining Theoretical Coherence within Relationship-Based Practice in Child and Family Social Work: The Systemic Perspective. British Journal of Social Work, 50(4), 1219. https://doi.org/10.1093/bjsw/bcz110

Published in:

British Journal of Social Work

Document Version:

Peer reviewed version

Queen's University Belfast - Research Portal:

Link to publication record in Queen's University Belfast Research Portal

Publisher rights

Copyright 2019 OUP. This work is made available online in accordance with the publisher's policies. Please refer to any applicable terms of use of the publisher.

\section{General rights}

Copyright for the publications made accessible via the Queen's University Belfast Research Portal is retained by the author(s) and / or other copyright owners and it is a condition of accessing these publications that users recognise and abide by the legal requirements associated with these rights.

Take down policy

The Research Portal is Queen's institutional repository that provides access to Queen's research output. Every effort has been made to ensure that content in the Research Portal does not infringe any person's rights, or applicable UK laws. If you discover content in the Research Portal that you believe breaches copyright or violates any law, please contact openaccess@qub.ac.uk. 


\title{
Attaining Theoretical Coherence Within Relationship-Based Practice in Child and Family Social Work: The Systemic Perspective
}

\author{
Stephen Coulter ${ }^{1} *$, Stanley Houston ${ }^{2}$, Suzanne Mooney ${ }^{1}$, \\ John Devaney (D) ${ }^{3}$ and Gavin Davidson ${ }^{4}$
}

\footnotetext{
${ }^{1}$ School of Social Sciences, Education and Social Work, Queens University Belfast, 6 College Park, Belfast BT7 1LP, UK

${ }^{2}$ School of Social Sciences, Education and Social Work, Queens University Belfast, 6 College Park, Belfast BT7 1LP, UK

${ }^{3}$ University of Edinburgh, Old College, South Bridge, Edinburgh EH8 9YL, UK

${ }^{4}$ School of Social Sciences, Education and Social Work, Queens University Belfast, 6 College Park, Belfast, BT7 1LP, UK
}

*Correspondence to Stephen Coulter, Lecturer in Social Work, School of Social Sciences, Education and Social Work, Queens University Belfast, 6 College Park, Belfast BT7 1LP, UK. E-mail: s.coulter@qub.ac.uk

\section{Abstract}

Social work practice has an essential, yet ambiguous, relationship with theory. This state of affairs is currently evident in the range of contemporary relationship-based practice (RBP) models being applied within Child and Family Social Work. This article argues that there is an urgent need for a theoretically coherent conceptualisation of these models to enable social work practitioners to embrace their common precepts and so enable more effective interventions. In contrast to attempts to show the distinctiveness of current models for reasons of fidelity, model identity and marketing, this unifying approach advocates for recognition of the commonality and complementarity of contemporary RBP models. The article argues that systemic theory which applies a social constructionist orientation can provide this coherence, helping social workers develop their practice in an informed way. In making this case, the emergent evidence base is noted and recommendations are made about how greater convergence and complementarity can be promoted. This article contributes to the debate about how practice and policy should be guided by theoretical ideas of coherence, alongside more utilitarian ideas advocating the importance of evidence and effectiveness. 
Keywords: Child and Family Social Work, model complementarity, relationship-based practice, systemic theory, theoretical coherence

Accepted: August 2019

\section{Introduction}

The social work profession (explicitly and perhaps implicitly) uses orienting theories and practice frameworks to describe and explain service user behaviour and how and why certain problems develop (Mailick, 1990). The relationship between theory and practice has however been a somewhat ambiguous affair, with the profession tending to adopt theories from the mainstream social sciences, including psychology, sociology, and cultural anthropology (Healy, 2005). For this reason, social work has tended to be seen as a less distinct professional discipline, one which prioritises practice and then looks for supporting explanatory theory (Hothersall, 2018). As a result, it is unclear whether informing theories always permeate into the consciousness of frontline social workers. For example, in a multi-method study of social workers' use of knowledge in their practice in statutory child protection, Osmond and O'Connor (2006, p. 5) found that 'most participants did not demonstrate a coherent, comprehensive and elaborated theory and research base to their practice'. Nevertheless, despite this apparent practice-theory disconnect, 'social workers base their practice on theoretical assumptions, 20 whether they are aware of them or not' (Munro, 1998, p. 6). Philosophical assumptions constitute a cognitive frame that determines professional reasoning in the field of social work and, if overlooked, can lead to vagueness in professional reasoning (Halvorsen, 2019). Therefore, to enhance clarity and the professional standing of social work, it is incumbent on the profession to develop practice models underpinned by informing theories (Healy, 2005) and, as this article does, to advocate for social work practice to be informed by a conscious, consistent use of theory. Rather than reignite redundant paradigm 'wars' (Payne, 2014), this article seeks to draw attention to the coherence with which the systemic 'lens' can be seen to underpin current RPB models. Indeed, this is part of the continuing story of the critical social work tradition which 'seeks to explain and transform various circumstances that social workers, carers and service users find themselves in, while connecting this to a structural analysis of those aspects of society that are 35 oppressive, unjust and exploitative' (Webb, 2019, p. xxxi).

A key aspect of orientating theories is how they position the social worker in relation to the service user, and the effect this has on both. In psycho-dynamic and person-centred relationship-based casework 
approaches, the professional is traditionally in the expert role and the social worker-service user relationship considered the primary vehicle for change (Murphy et al., 2013). Family and community environments are understood as contributing to the aetiology and maintenance of difficulties, but less emphasis is given to their potential to contribute to the resolution of those difficulties.

The contemporary systemic approach, in contrast, seeks to foreground services users' expertise and sees difficulties arising in the context of family and community networks, which are also viewed as potential resources for the resolution of those difficulties (Madsen, 2013). In this way, service user relationships with the wider network are emphasised, so that they, together with key partners (formal and informal), can enable sustainable change. This brings a significant shift in the role of the social worker who can now be positioned as a facilitator in interpersonal processes: one who elicits the resourcefulness and know-how of the client and their network. In affording this perspective, the systemic approach has the potential to satisfy the need for both theoretical validity (its acuity in explaining human behaviour) and practice validity (its usefulness in effecting change) (Sheppard, 1998; Wolming and Wikström, 2010) in social work.

By way of clarification, we have used the phrase 'contemporary systemic approach' to refer to that body of knowledge and practice skills that adopts a social constructionist orientation and focuses on the relationships between people, their local environments, the socio-political systems in which their lives are embedded, and the cultural mores and messages that impinge on their life (Hedges, 2005). This approach originally emerged from family systems theory and led to the development of systemic family therapy as a specific psychotherapeutic modality, but has since evolved to a range of creative and innovative practice applications.

In the array of relational and collaborative approaches now available to the social work practitioner within Child and Family Social Work in the UK, Ireland, North America, Europe and Australasia (such as Reclaiming Social Work (RSW), Safe and Together, Signs of Safety (SoS), Family Group Conferencing (FGC), to name a few), their common characteristic is the recognition and bolstering of the latent strengths and expertise of the service user and their networks. Building on this important foundation is a re-conceptualisation of what it means to engage in person-centred practice. That is, the social worker is guided, through these contemporary relationship-based practices (RBPs), to involve service users, their families, broader networks and relevant professionals in a cooperative, co-constructive endeavour to find solutions to pressing concerns and difficulties.

Related to such developments, Munro et al. (2016) argues that there must be a 'theoretical coherence' that informs practice and that guides 
what social workers actually do in their work with children and families; in other words, it is not simply a matter of delivering new systems and structures nor providing isolated training events. We contend that the contemporary systemic approach embraces Munro's recommendations by offering such coherence in support of frontline practices, but that it requires active promotion, rather than assuming that coherence will arise implicitly.

The remainder of this article makes the case for this core contention and is structured as follows. First, we describe the socio-political context in which the contemporary models of RBP have arisen. This section highlights the important drivers of change towards the renaissance of 'relationship' as a pivotal change concept in Child and Family Social Work. Secondly, the common systemic foundations of contemporary models of RBP will be highlighted and the philosophical and theoretical bases of the systemic approach delineated. Lastly, we argue that the systemic approach offers a coherent and unifying theoretical base and set of core skills that social workers can draw upon to make connections between competing RBP models.

\section{Context}

Over the last two decades there have been a number of important political, social and economic influences that have shaped child welfare systems and the response to child protection concerns specifically (Berrick et al., 2017; Collins, 2018). Internationally, and specifically in the UK, an important recent factor has been the financial crash of 2008, and the subsequent economic recession and retrenchment that has led to policies of reining in public expenditure and raising revenue.

The Government's public expenditure policies have involved significant reductions in the scope and amount of welfare benefits, with average reductions of budgets by 19 per cent across government departments over a four-year period (HM Treasury, 2010). The significant budget reduction for children's social care services paradoxically occurred at the same time as increasing demand for services, partially as a result of the aforementioned economic crisis and the Government's response. For example, there has been a 7 per cent increase in referrals of children in need, and a 3 per cent increase in the numbers of children 'looked after' in England between 2010 and 2017, while budgets have decreased by 9 per cent in real terms during the same period (Department for Education, 2017a). In England, for example, the impact of these reductions has fallen disproportionately on the local authorities in the most deprived areas (Featherstone, 2018). As Keddell (2018) notes in the New Zealand context, the scaling back of social protections such as state welfare benefits, a decrease in affordable quality housing, and the 
reduction of funding to non-governmental organisations (NGOs) commissioned to provide preventative child welfare services, is remarkably similar to the situation in the UK, with similar depressing results.

This bleak economic picture has adversely influenced the quality of public services, while opening up space for Governments to introduce new models of service provision and delivery (Randma-Liiv and Kickert, 2017). Additionally, the tragic death of baby Peter Connelly and other high profile child deaths in other jurisdictions (Keddell, 2018) has driven home the inadequacy of bureaucratic attempts to address problems of professional practice in Child and Family Social Work (Laming, 2009) and highlighted the truism that, 'ultimately it is not systems but people-and in particular key professionals-who act to protect children, and it was widely considered evident that a new approach was necessary' (Forrester et al., 2013, p. 11).

As a consequence of these pressures local authorities have been moved to re-imagine how they deliver services, including social care to children and their families. The UK government commissioned Eileen Munro to make recommendations for strengthening the child protection system (Munro, 2011). In summary, Munro called for a more childcentred form of practice, with support and help offered early; a need to reduce bureaucracy to liberate staff to focus on direct contact with children and families; and a management system that facilitated greater professional autonomy.

In 2014, central government launched the Children's Social Care Innovation Programme in England with a budget of $£ 200$ million, with the aim of supporting innovative ideas to flourish and enabling policy and practice to be driven by evidence and best practice (Department for Education, 2017a). As a consequence of this stimulus funding, local authorities have experimented with new ways of working including initiatives embracing a whole system redesign (Laird et al., 2018), such as the RSW model (Ferguson, 2007), and more specific interventions and focused changes, such as the adoption of FGC as a distinct method of working (Van Alphen, 2013; Metze et al., 2015). The SoS approach (Turnell and Edwards, 1999; Turnell and Murphy, 2017) is being widely introduced in local authorities in England, Scotland and Wales, and has been adopted as the national model of practice in both jurisdictions in Ireland, while FGC (Van Alphen, 2013) has become embedded in Children's Social Care and Youth Justice settings.

Although too early to judge the efficacy of these RPB approaches, a preliminary study has revealed encouraging results. Baginsky et al. (2017) in an evaluation of 10 SoS pilot schemes found social workers and their managers were very positive about it as a practice framework and, despite a number of organisational challenges, were optimistic that it would over time strengthen their service through greater family involvement, promoting a clearer understanding of statutory concerns and 
greater focus on goals. However, a more recent review in relation to SoS has concluded that there is little robust research evidence of positive impact (Sheehan et al., 2018). What is clear is that contemporary RBP models have the capacity to affect service users' perception of social workers and their objectives. Buckley et al. (2011), for example, highlight service users' ability to clearly discern between an investigative and a family centred approach to child protection work. The largely positive feedback from service users should not be lightly dismissed, particularly in the context of child protection social work where parental engagement can be challenging (Baginsky et al., 2017; Sheehan et al., 10 2018).

\section{Relationship-based practice models}

Featherstone et al. (2018, p. 100) note that RBP models are still primarily theorised in terms of psychodynamic thinking:

While writers on contemporary RBP have emphasised the importance of an integrated understanding of individual and structural causes of social distress and practice within an anti-oppressive framework, theorising has primarily focused on intra psychic and interpersonal dynamics.

For example, Bryan et al. (2016, p. 229) state:

We believe that social worker-service user relationships are strengthened by a deeper understanding of the psychodynamics and emotions of those relationships, set within the systems and organisational contexts in which those interactions take place.

The inference in this 'hybrid' approach is that psychodynamic ideas are useful for the personal/interpersonal aspects of social work practice and systemic theory is useful for informing the interaction with wider impinging systems (Hingley-Jones and Ruch, 2016). This bifurcation evidences a lack of understanding of the contemporary systemic approach which offers a relational conceptualisation of the person, and service provider/user interactional processes, distinct from psychodynamic concepts (Kraus, 2019). We contend, affirmatively, that a systemic approach has its own distinct conceptualisation of the person which does not need to rely on psychodynamic concepts, important as they are.

In this vein, one does not have to 'dig deep', or creatively interpret the literature published by the initiators of contemporary RBP models (and their associated commentators) to discover the central influence of systemic theory on their development. For example, with regard to a model implemented in parts of the UK, we note the following description, that 'a systems approach forms the theoretical basis for Reclaiming Social Work' (Cross et al., 2010, p. 161). Indeed, an evaluation of the Systemic Unit model, as a mechanism for implementing the vision of the 
RSW strategy, notes that the approaches with the best evidence of positive impact are based on systemic theoretical models, which it states, '... creates a unifying methodology, language and understanding that supports multi-disciplinary working and promotes consistency in families' experience' (Department for Education, 2017b, p. 1). With respect to two RBP models most strongly embedded in international social work practice, Turnell et al. (2018, p. 3) states 'Signs of Safety follows a systemic approach to change and problem solving', and Van Alphen (2013, p. 3) comments that a Family Group Conference has 'an inherent systemic approach'. Table 1 is presented as a graphic representation further evidencing the commonality and systemic complementarity between these three widely implemented RBP models.

Despite this common heritage, contemporary RBP models are often presented as separate, internally coherent models, with different purposes, and bespoke interventions or techniques. This means that the underpinning systemic connection between these models/approaches has not been sufficiently grasped. The lack of cross-referencing between these new models compounds the difficulty, with social workers perceiving a plethora of distinct models. As a consequence, there is a risk of fragmentation with practitioners encountering separate training programmes, assessment formats, and different languages. At times they have been experienced as isolated initiatives that do not coherently complement existing practices, and involve adding tasks to highly demanding, extant workloads (Pecora et al., 2009; Davidson et al., 2012). We contend, alternatively, that there is merit in moving towards greater conceptual coherence and connection through acknowledging the models' common systemic theoretical underpinnings.

Furthermore, within the politics of theory promotion, policy and practice, there is a danger of unhelpful competition between the different approaches and methods. This is sometimes dependant on the perceived expert or organisational power of those promoting a specific way of working, which can further skew the field. Thus, it can be challenging for the frontline social worker, and even service commissioners, to determine how a number of practice models can be applied in a theoretically coherent and integrated way in the everyday pressing world of legal, policy and administrative imperatives (Bentovim et al., 2018).

\section{Philosophical precepts of systemically informed relationship-based practice}

Having established that RBP developments, currently being promoted within 're-imagined' Child and Family Social Work services, typically promote a systemic orientation (Featherstone et al., 2014), we now argue 
that, at a deeper level, such approaches also share common, philosophical precepts.

Systems theory is an interdisciplinary, meta-theory which seeks to explain the nature of complex systems in nature, society and science. A system is defined as any unit structured on feedback, while a social system is a person or group of persons, who function interdependently to accomplish common goals over an extended period of time (Luhmann, 2012). Feedback over time becomes identified as a pattern, and the identification of the pattern introduces the concept of the observer of the pattern; that is, no pattern exists without someone who punctuates events in such a way that they are seen as a pattern (Maturana, 1988). Pattern, in turn, creates its own context, and it is through context that events or behaviours acquire meaning. Thus, meaning and behaviour are seen to be in a recursive or circular relationship. People voluntarily behave as they do because they have certain beliefs about the context they are in, and these beliefs are then supported or challenged by the feedback on their behaviour. Meanings that are attributed to behaviour can be arranged in a hierarchical structure. While some meanings come from abstract societal-level constructs such as religion and culture, other meanings come from lower order contexts, or more specific levels such as dyadic relationships (Wasserman and Fisher-Yoshida, 2017). As people interact, they become a unique system and their behaviour has meaning for the larger system around them.

Allied to these philosophical conceptualisations of the interactional, circular and contextual premise of human behaviour, social constructionism emerged as part of the post-positivist movement in the1960s and 1970s. It proved to be a powerful perspective in the social sciences by rejecting the notion of realities that exist independent of the observer (Burr, 2015) and making it 'possible to think not only of the individuals re-construing aspects of themselves, but of re-thinking whole social categories, such as gender, sexuality, race, disability and illness' (Burr, 1998, p. 13). The contribution of the social constructionist perspective to contemporary systemic theory and practice is difficult to overstate. Social constructionism has re-emphasised the social, rather than the intrapsychic or psychological, nature of 'the mind' (Valsiner and Van der Veer, 2000) and the centrality of social 'relationship' for survival, identity and well-being (White, 2008). It allows the conceptualisation of the 'self' to shift from that of the 'individual psyche or autonomous separate self' to a relational self (Fishbane, 2001), a 'being-in-the-world with other human beings'. The key realisation is that if we understand something as a social construction, rather than as 'a given', it can then be fashioned differently, and thus action for change, to co-create alternative social constructions, may emerge. This is a central tenet of systemically informed RBP that through dialogue, social realities are continually being created and re-created, rather than simply reflecting pre-existing realities. Thus, 45 
the act of speaking is neither neutral nor passive, but rather brings forth a particular reality in which meaning is negotiated between speakers (Gehrke, 2009). Dialogue, therefore, is inherently political, with power to impact all aspects of people's lived experience. Society is replete with the capacity to create dominant stories that tend to shape individual life narratives by influencing how meaning is ascribed to particular life events and choices made about what gets 'storied' and what does not (Denborough, 2014). It follows that language can be used to label, dehumanise, and objectify or, alternatively, to empower by liberating people from oppressive and constraining, dominant narratives. Consequently, it is incumbent on social workers to be cognisant of the specific kind of dialogical processes they enter when they engage with service users in RBP encounters. Collaboratively helping clients seek new meanings, envisage new understandings and possible solutions, through dialogue, can supersede the notion of the social worker as a techno-rational (Parton, 2000) expert as the preferred modality of social work practice.

The social constructionist influence over the past 30 years has resulted in the creation of a range of collaborative models of systemic practice in which the professional is in a co-constructivist relationship with the service user. These include Milan Systemic Family Therapy (Boscolo et al., 1987), Solution Focused Brief Therapy (De Shazer, 1988), Collaborative Language Systems Model (Anderson, 1997) and Narrative Therapy (White, 2007). It is these systemic therapeutic approaches, which have influenced many of the models of contemporary RBP models now being implemented in Child and Family Social Work. Pendry (2012, p. 28) comments, 'The key idea that is consistent throughout this development is that problems are embedded within relationships, that is, problems are understood as being interpersonal rather than intrapsychic.'

The organising thesis of the systemic approach is its relational and interactional focus recognising that "we are always and inevitably part of a wider "ecology" within political, economic and cultural contexts and that everything in our social lives is connected through our relationships and co-created through and within our communication processes' (Hedges, 2005, p. 184). It offers therefore different conceptualisations of human problems, with 'individual distress ... no longer ... seen only as the product of the individual's psychology, but rather as a complex iterative process that is understood in terms of relational dynamics at many levels of contextual understanding' (Vetere and Dallos, 2003, p. 7), including relational, group, cultural and societal levels of explanation.

\section{Implications for policy and practice}

The contemporary systemic approach, rooted in systemic theory and a social constructionist philosophy, 'can enable social work to move closer 


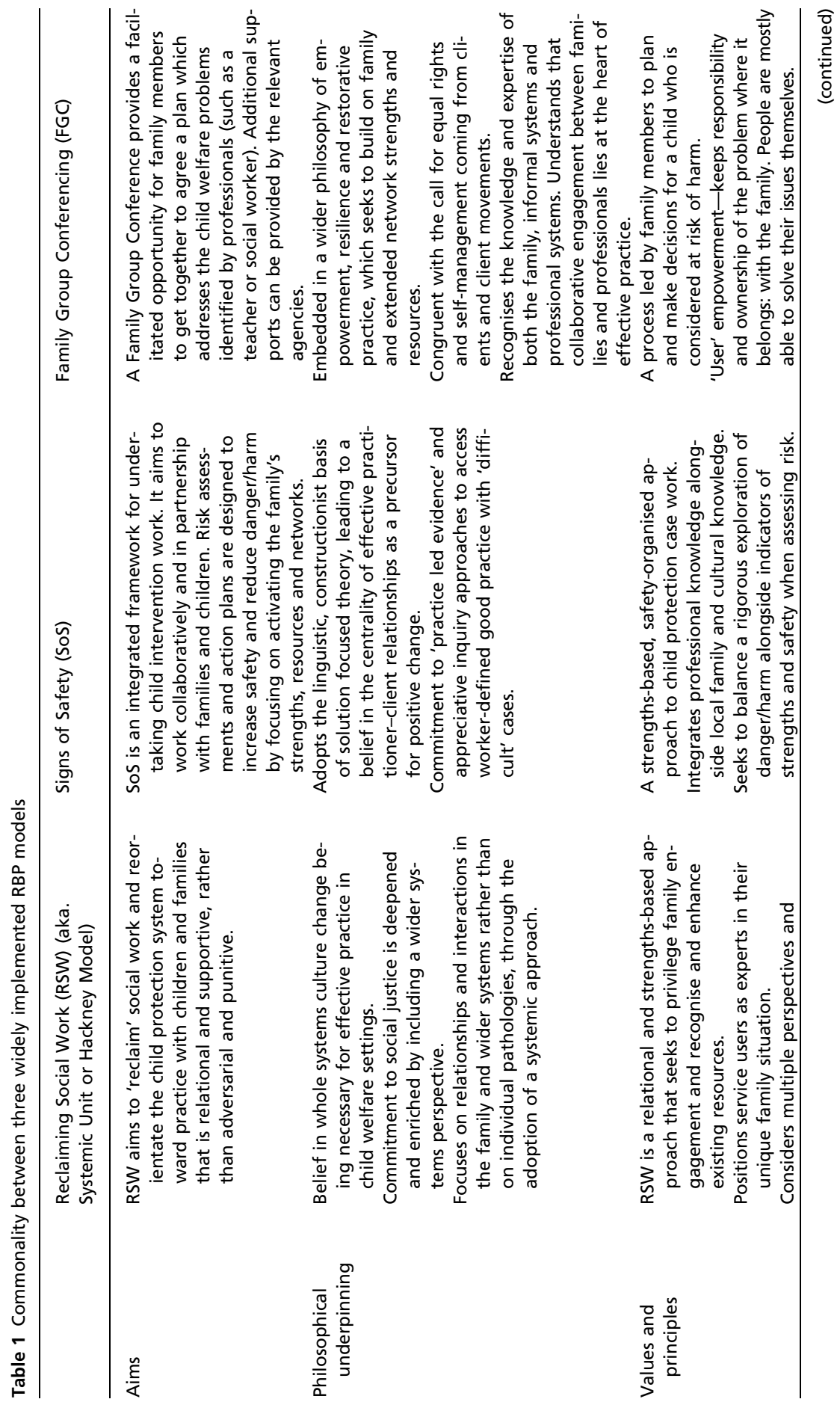




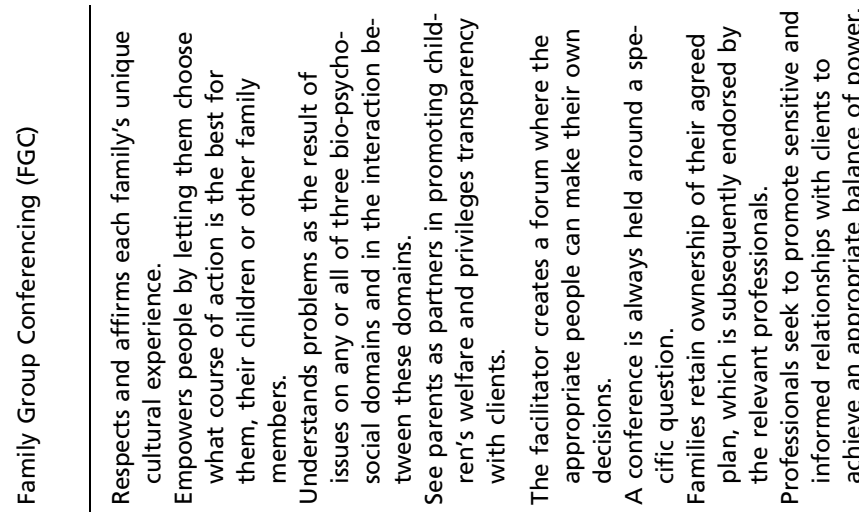

(1)

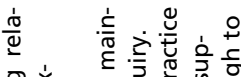

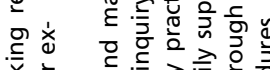

咅言

>

ऐัष

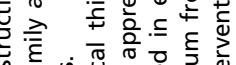

ธิธี

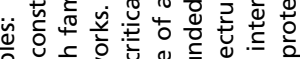

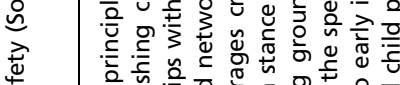

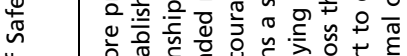

ํㅡㄴ

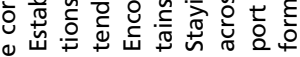

ㄷํㅇํำ

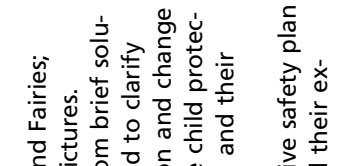

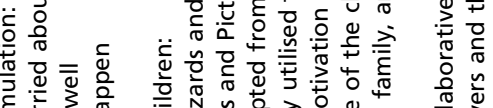

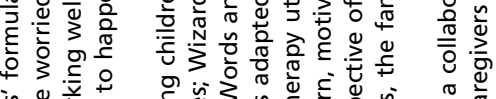

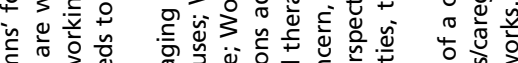
है O

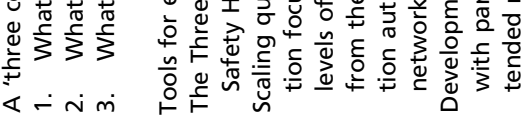

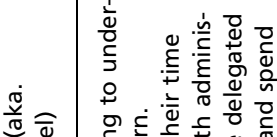

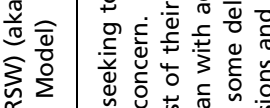

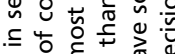

立咅

3

$\frac{\pi}{2}$

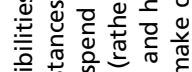

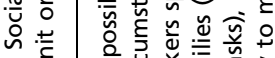

ס

.气

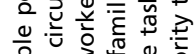

元

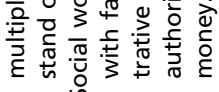

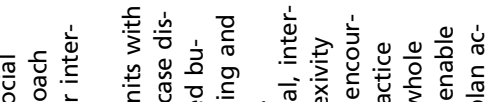

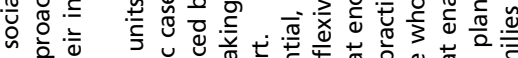

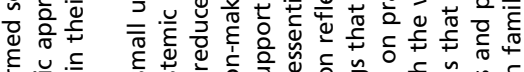

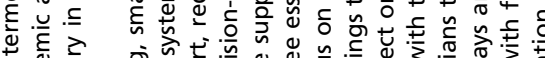

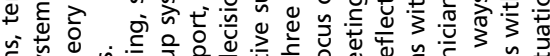

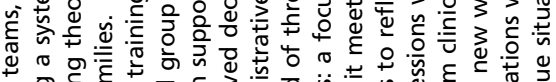

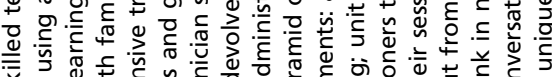

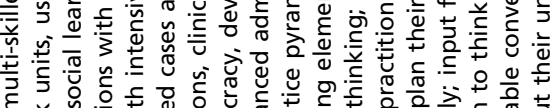

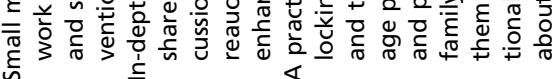


Page 12 of 19 Stephen Coulter et al.

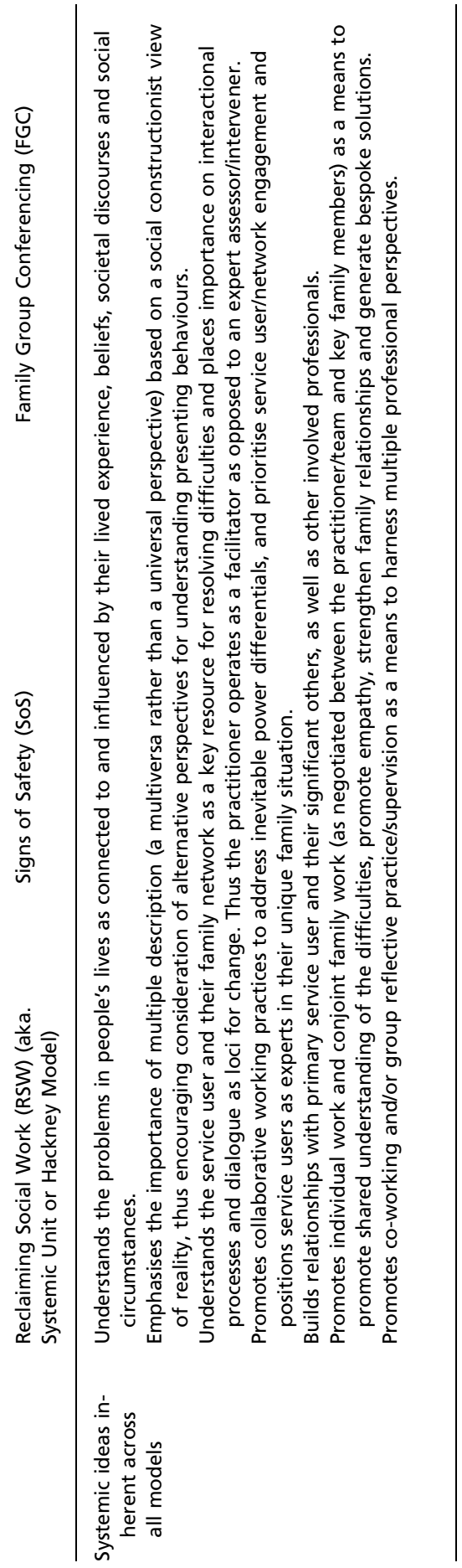


to its claim to be "social" work providing the social worker with alternatives for practice thinking that allow practitioners to challenge dominant discourses and strengthen service users' narratives' (Witkin, 2012, p. 6). This holistic position fits well with the Global Definition of Social Work (IFSW, 2014) and the values and ethics of the profession (BASW, 2014) as well as the intentions of RBP which ' $\ldots$ challenges the prevailing trends which emphasize reductionist understandings of human behaviour and narrowly conceived bureaucratic responses to complex problems' (Ruch, 2005, p. 111).

This 'person-in-context' systemic perspective can mitigate an overemphasis on individual responsibility as the primary factor in the aetiology of service users' problems, and is congruent with Ungar's (2017, p. 1279) finding that, "it is the environmental factors that "count more" than individual biology or temperament to psycho-social outcomes, especially when risk exposure is high'. Tellingly, Ungar argues that it is when environments change, people change, at biological, psychological and social levels. Nevertheless, RBP models have had to address the concern that they may lack sufficient focus on issues of risk or fail to give enough credit to the technicalities of traditional social casework (Hayes et al., 2014). This concern, however, seems largely unsubstantiated as evidence emerges that a positive professional and service user alliance can be formed even in the context of complex and adversarial child protection services (Maiter et al., 2006), through the mindful and judicious use of power combined with a 'humanistic attitude and style that stretches traditional professional ways-of-being' (De Boer and Coady, 2007, 25 p. 32).

When a social worker begins to work with a child or family a new system is created. The social worker is not an external observer or analyst of the child and his or her family and community system, but rather they join the family to form a new system to help understand and address presenting difficulties and concerns. Together they can co-create a social system to mobilse innate resources to address the professionals' and family's concerns regarding child well-being. If the social worker has awareness of the commonality among contemporary RBP models and feels confident to use a range of methods in a complementary fashion, then their practice is likely to be enhanced. For example, a social worker working within the SoS approach may decide to facilitate a Family Group Conference to ascertain the family's views and proposed safety plan regarding an issue of risk.

Integrated practice of this kind requires support from managers and service commissioners who have an understanding of their common systemic origins and can facilitate more fertile and flexible practice through promoting complementarity, rather than separate models. Hence, we advocate that all RBP training programmes should explicitly draw attention to their systemic commonality with other RPB models and promote 
practice congruence. Furthermore, Bostock et al. (2017, p. 10) found that, 'training in systemic practice and the quality of group systemic case discussion had a very strong relationship with the quality of practice with families'. Therefore, social work managers should enable their staff to appreciate the range of options available within this 'family' of contemporary models. Formal supervision and team meetings might benefit from adopting a range of methods and techniques available within the 'family' of systemically informed models. One can also see the benefit of an induction to general systemic thinking and practice for all early career social workers and participation in post-qualifying systemic practice and family therapy courses for key staff managing and implementing these contemporary RBP models.

\section{Conclusion}

Child protection systems internationally are experiencing a crisis of confidence, and a subsequent re-imagining of both purpose and form (Kruk, 2015; Featherstone et al., 2018; Keddell, 2018; Kim and Drake, 2018). Within the UK, the general shift in Child and Family Social Work policy and service development to systemically informed RBP approaches provides an excellent opportunity to move towards an approach to working with families which acknowledges, analyses and addresses their immediate issues in the context of their relationships, the stressors of their environment and the impact of wider societal processes and discourses. While there is an increasing international consensus that the move away from risk and deficit focused policy and services is positive (Featherstone et al., 2018; Kim and Drake, 2018), a sometimes bewildering range of possible alternative perspectives and models have emerged. The contemporary systemic approach is the current common philosophical underpinning for RBP models in Child and Family Social Work. This article seeks to highlight that without sufficient understanding of the theoretical coherence of these distinct RBP approaches, they may be experienced and implemented as separate, even competing and possibly bewildering, initiatives. Systemic theory and practice skills provide a robust framework to bring these developments together to further enhance practice and maximise overall effectiveness.

The articulation of a coherent systemic theoretical framework for contemporary RBP models in Child and Family Social Work is aimed at progressing therapeutic convergence rather than invoking a new paradigm war. Indeed, a systemic, social constructionist theory, with its focus on how a group of people have the power to create a common dialogue, offers a creative template for such convergence. Our foundational argument is that systemic theory provides a unifying discourse adding coherence and connection to models of intervention that rightly emphasise 
the centrality of human relationship. As Ungar (2017, p. 1283) points out:

To understand change, we need maps that are as complex as the territory they explain. If the individual's problems are multisystemic (e.g. reflecting neurodevelopmental challenges, housing problems and exposure to violence), then adaption of multiple systems will be required to improve individual well-being.

The contemporary systemic approach provides that 'map', offering Child and Family Social Work theoretical coherence across multiple RBP models as well as a set of integrating practice concepts, methods and skills that can promote practitioner effectiveness and flexibility.

Conflict of interest statement. None declared.

\section{References}

Anderson, H. (1997) Conversation, Language, and Possibilities: A Postmodern Approach to Therapy, New York, Harper Collins.

Baginsky, M., Moriarty, J., Manthorpe, J., Beecham, J. and Hickman, B. (2017) Children's Social Care Innovation Programme Evaluation Report 48 - Evaluation of Signs of Safety in 10 Pilots. London, Department for Education.

BASW (2014) Code of Ethics for Social Work, Birmingham, BASW.

Bentovim, A., Vizard, E. and Gray, J. (2018) 'Editorial perspective: Treatment of complex maltreatment-beyond the NICE guideline? Manuals, muddles or modules', Child and Adolescent Mental Health, 23(3), pp. 297-300.

Berrick, J., Dickens, J., Pösö, T. and Skivenes, M. (2017) 'A cross-country comparison of child welfare systems and workers' responses to children appearing to be at risk or in need of help', Child Abuse Review, 26(4), pp. 305-19.

Boscolo, L., Cecchin, G., Hoffman, L. and Penn, P. (1987) Milan Systemic Family Therapy, New York, Basic Books.

Bostock, L., Forrester, D., Patrizo, L., Godfrey, T., Zonouzi, M., Antonopoulou, V., Bird, H. and Tinarwo, M. (2017) Scaling and Deepening the Reclaiming Social Work Model Evaluation Report, London, Department for Education, available online at: https://assets.publishing.service.gov.uk/government/uploads/system/uploads/ attachment_data/file/625227/Scaling_and_deepening_the_Reclaiming_Social_ Work_model.pdf (accessed April 26, 2018).

Bryan, A., Hingley-Jones, H. and Ruch, G. (2016) 'Relationship-based practice revisited', Journal of Social Work Practice, 30(3), pp. 229-33.

Buckley, H., Carr, N. and Whelan, S. (2011) "Like walking on eggshells": Service user views and expectations of the child protection system', Child and Family Social Work, 16(1), pp. 101-10.

Burr, V. (1998) 'Overview: Realism, relativism, social constructionism and discourse', in Parker, I. (ed.), Social Constructionism, Discourse and Realism, pp. 13-26, 40 Chap. 2, London, SAGE.

Burr, V. (2015) Social Constructionism, 3rd edn, London, Routledge. 
Collins, M. E. (2018) 'Comparative analysis of state policymaking in child welfare: Explaining policy choices', Journal of Comparative Policy Analysis: Research and Practice, 20(4), pp. 370-86.

Cross, S., Hubbard, A. and Munro, E. (2010) Reclaiming Social Work - Independent Evaluation, available online at: https://secure.toolkitfiles.co.uk/clients/28663/site data/files/Eileen-Munro.pdf (accessed October 8, 2018).

Davidson, G., Bunting, L. and Webb, M. A. (2012) Families Experiencing Multiple Adversities: A Review of the International Literature. Barnardos, available online at: http://www.barnardos.org.uk/14796_ni_pp_briefing_paper_literature_review_lr. pdf (accessed July 27, 2019).

Denborough, D. (2014) Retelling the Stories of Our Lives; Everyday Narrative Therapy to Draw Inspiration and Transform Experience, Adelaide; New York, NY, W. W. Norton and Company.

De Boer, C. and Coady, N. (2007) 'Good helping relationships in child welfare: Learning from stories of success', Child and Family Social Work, 12(1), pp. 32-42.

Department for Education (2017a) Children's Services: Spending, 2010-11 to 2015-16, London, HMSO.

Department for Education (2017b) Learning Summary 3. Implementing Systemic Models of Social Work, London, HMSO, available online at: https://innovationcsc. co.uk/wp-content/uploads/2017/11/2.26_Social-Work.pdf (accessed June 14, 2019).

De Shazer, S. (1988) Clues: Investigating Solutions in Brief Therapy, New York, NY, Norton.

Featherstone, B., White, S. and Morris, K. (2014) Re-imagining Child Protection: Towards Humane Social Work with Families, Bristol, Policy Press.

Featherstone, B., Gupta, A., Morris, K. and White, S. (2018) Protecting Children: A 25 Social Model, Bristol, Policy Press.

Ferguson, I. (2007) Reclaiming Social Work: Challenging Neo-Liberalism and Promoting Social Justice, London, SAGE.

Fishbane, M. D. (2001) 'Relational narratives of the self', Family Process, 40(3), pp. 273-90.

Forrester, D., Westlake, D., McCann, M., Thurnham, A., Shefer, G., Glynn, G. and Killian, M. (2013) Reclaiming Social Work? An Evaluation of Systemic Units as an Approach to Delivering Children's Services: Final Report of a Comparative Study of Practice and the Factors Shaping It in Three Local Authorities, Bedfordshire, Tilda Goldberg Centre for Social Work and Social Care, University of 35 Bedfordshire.

Gehrke, P. J. (2009) The Ethics and Politics of Speech: Communication and Rhetoric in the Twentieth Century, Carbondale, IL, Southern Illinois University Press.

Halvorsen, T. (2019) 'Philosophy of social work - a new and advantageous field of training and research', Journal of Social Work Practice, 33(1), pp. 55-66.

Hayes, D., McGuigan, K., Pinkerton, J. and Devaney, J. (2014) Evaluation of Safety in Partnership: Phase Two Report - Perspectives on Practice, Queens University Belfast, available online at: https://pure.qub.ac.uk/portal/files/18568620/Safety_in_ Partnership_Evaluation_Phase_Two_Report_Perspectives_on_Practice.pdf (accessed December 6, 2018).

Healy, K. (2005) Social Work Theories in Context: Creating Frameworks for Practice, London, Palgrave Macmillen.

Hedges, F. (2005) An Introduction to Systemic Therapy with Individuals a Social Constructionist Approach, Hampshire, Palgrave MacMillan. 
Hingley-Jones, H. and Ruch, G. (2016) 'Stumbling through'? Relationship-based social work practice in austere times', Journal of Social Work Practice, 30(3), pp. 235-48.

HM Treasury (2010) Spending Review, HMSO, available online at: https://assets.pub lishing.service.gov.uk/government/uploads/system/uploads/attachment_data/file/ 203826/Spending_review_2010.pdf (accessed December 6, 2018).

Hothersall, S. J. (2018) 'Epistemology and social work: Enhancing the integration of theory, practice and research through philosophical pragmatism', European Journal of Social Work, 22(3), 860-70.

IFSW (2014) 'Global definition of social work' available online at: https://www.ifsw. org/what-is-social-work/global-definition-of-social-work/ (accessed November 26, 2018).

Keddell, E. (2018) 'The vulnerable child in neoliberal contexts: The construction of children in the Aotearoa New Zealand child protection reforms', Childhood, 25(1), pp. 93-108.

Kim, H. and Drake, B. (2018) 'Child maltreatment risk as a function of poverty and race/ethnicity in the USA', International Journal of Epidemiology, 47(3), pp. 780-7.

Kraus, B. (2019) 'Relational constructivism and relational social work', in Webb, S. A. (ed.), The Routledge Handbook of Critical Social Work, pp. 93-104, London, Routledge.

Kruk, E. (2015) 'Child and family social work in Canada: Issues and challenges within a neo-liberal political context', in Social Work in a Global Context, pp. 104-20, London, Routledge.

Laird, S. E., Morris, K., Archard, P. and Clawson, R. (2018) 'Changing practice: The possibilities and limits for reshaping social work practice', Qualitative Social Work, 17(4), pp. 577-93.

Laming, L. (2009) The Protection of Children in England: A Progress Report, London, HMSO.

Luhmann, N. (2012) Introduction to Systems Theory, Cambridge, Polity Press.

Madsen, W. C. (2013) Collaborative Therapy with Multi-Stressed Families, 2nd edn, New York, Guilford Press.

Healy, K. (2014) Social Work Theories in Context: Creating Frameworks for Practice. 2nd edn. London, Palgrave Macmillan.

Maiter, S., Palmer, S. and Manji, S. (2006) 'Strengthening social worker-client relationships in child protective services', Qualitative Social Work: Research and Practice, 5, 167-86.

Maturana, H. R. (1988) 'Ontology of observing: The biological foundations of self-consciousness and the physical domain of existence'. In: Donaldson R. E. (ed.). Texts in cybernetic theory: An in-depth exploration of the thought of Humberto Maturana, William T. Powers, and Ernst von Glasersfeld. American Society for Cybernetics (ASC). Available at https://cepa.info/597 (accessed July 28, 2019).

Metze, R. N., Abma, T. A. and Kwekkeboom, R. H. (2015) 'Family group conferencing: A theoretical underpinning', Health Care Analysis, 23(2), pp. 165-80.

Munro, E. (1998) Understanding Social Work: An Empirical Approach. London, The Athlone Press.

Munro, E. (2011) The Munro Review Of Child Protection: Final Report. A Child-Centred System, London, Department for Education, available online at: 
https://www.gov.uk/government/publications/munro-review-of-child-protection-fi nal-report-a-child-centred-system (accessed April 26, 2018).

Munro, E., Turnell, A. and Murphy, T. (2016) 'You Can't Grow Roses In Concrete' Organisational Reform to Support High Quality Signs of Safety Practice Action Research Final Report, Signs of Safety English Innovations Project, Munro, Turnell and Murphy Child Protection Consultancy, available online at: http://cdn.basw.co. uk/upload/basw_102921-2.pdf (accessed March 23, 2019).

Murphy, D., Duggan, M. and Joseph, S. (2013) 'Relationship-based social work and its compatibility with the person-centred approach: principled versus instrumental perspectives', British Journal of Social Work, 43(4), pp. 703-19.

Osmond, J. and O'Connor, I. (2006) 'Use of theory and research in social work practice: Implications for knowledge-based practice', Australian Social Work, 59(1), pp. 5-19.

Parton, N. (2000) 'Some thoughts on the relationship between theory and practice in and for social work', The British Journal of Social Work, 30(4), pp. 449-63.

Payne, M. (2014) Modern Social Work Theory, 4th edn, New York, NY, Palgrave Macmillan.

Pecora, P. J., Whittaker, J. K., Maluccio, A. N., Barth, R. P., DePanfilis, D. and Plotnick, R. D. (2009) The Child Welfare Challenge: Policy, Practice, and Research, Piscataway, NJ, Aldine Transaction.

Pendry, N. (2012) 'Systemic practice in a risk management context', in Goodman, S. and Trowler, I. (eds), Social Work Reclaimed: Innovative Frameworks for Child and Family Social Work Practice, pp. 26-33, Chap. 3, London, Jessica Kingsley.

Randma-Liiv, T. and Kickert, W. (2017) 'The impact of the fiscal crisis on public administration reforms: Comparison of 14 European countries', Journal of 25 Comparative Policy Analysis: Research and Practice, 19(2), pp. 155-72.

Ruch, R. (2005) 'Relationship-based practice and reflective practice: Holistic approaches to contemporary child care social work', Child Family Social Work, 10(2), pp. 111-23.

Sheehan, L., O'Donnell, C., Brand, S. L., Forrester, D., Addis, S., El-Banna, A., Kemp, A. and Nurmatov, U. (2018) Signs of Safety: Findings from a Mixed-Methods Systematic Review Focussed on Reducing the Need for Children to $B e$ in Care, London, What Works Centre for Children's Social Care.

Sheppard, M. (1998) 'Practice validity, reflexivity and knowledge for social work', The British Journal of Social Work, 28(5), pp. 763-81.

Turnell, A. and Edwards, S. (1999) Signs of Safety: A Solution and Safety Oriented Approach to Child Protection, New York, NY, Norton.

Turnell, A. and Murphy, T. (2017) Signs of Safety: A Comprehensive Briefing Paper, 4th edn, East Perth, Resolutions Consultancy.

Turnell, A., Munro, E., and Murphy, T. (2018) Response to the What Works Centre 2018: Review of the Signs of Safety, Munro, Turnell and Murphy Child Protection Consultancy, available online at: https://www.communitycare.co.uk/2018/11/22/ munro-consultancy-signs-safety-gaps-already-addressed/ (accessed October 17, 2018).

Ungar, M. (2017) 'Which counts more: Differential impact of the environment or differential susceptibility of the individual?', The British Journal of Social Work, 47(5), pp. 1279-89.

Valsiner, J. and Van der Veer, R. (2000) The Social Mind: Construction of the Idea, Cambridge, Cambridge University Press. 
Van Alphen, M. (2013) 'Family group conferencing: A systemic, socially responsible way to support individuals with problems', available online at: http://www.markus vanalphen.com/wp-content/uploads/2017/06/IRDO-Family-group-conferencing.pdf (accessed April 26, 2018).

Vetere, A. and Dallos, R. (2003) Working Systemically with Families: formulation, Intervention and Evaluation, London, Karnac.

Wasserman, I. C. and Fisher-Yoshida, B. (2017) Communicating Possibilities: A Brief Introduction to the Coordinated Management of Meaning (CMM), Chagrin Falls, $\mathrm{OH}$, Taos Institute Publications.

Webb, S. A. (2019) 'Introduction: Critical social work and the politics of transforma- 10 tion', in Webb, S. A. (ed.), The Routledge Handbook of Critical Social Work, pp. $\mathrm{xxx}-\mathrm{xliv}$, London, Routledge.

White, M. (2007) Maps of Narrative Practice, New York, NY, Norton.

White, S. (2008) But What Is Wellbeing? A Framework for Analysis in Social and Development Policy and Practice, Bath, Centre for Development Studies.

Witkin, S. L. (ed.) (2012) Social Construction and Social Work Practice: Interpretations and Innovations, New York, NY, Columbia University Press.

Wolming, S. and Wikström, C. (2010) 'The concept of validity in theory and practice', Assessment in Education: Principles, Policy and Practice, 17(2), pp. 117-32. 